\title{
Monitoring leptin activity using the chicken leptin receptor
}

\author{
Gideon Hen, Sera Yosefi, Ana Ronin, Paz Einat ${ }^{1}$, Charles I Rosenblum ${ }^{2}$, Robert J Denver ${ }^{3}$ \\ and Miriam Friedman-Einat \\ Institute of Animal Science, Agricultural Research Organization, Volcani Center, PO Box 6, Bet Dagan 50250, Israel \\ ${ }^{1}$ Consulting and Inventions, Nes Ziona, Moshe Levi 45A, 74207 Israel \\ ${ }^{2}$ Department of Metabolic Disorders-Diabetes, Merck Research Laboratories, Rahway, New Jersey 07065, USA \\ ${ }^{3}$ Department of Molecular, Cellular and Developmental Biology, The University of Michigan, 830 North University Avenue, Ann Arbor, \\ Michigan 48109-1048, USA \\ (Correspondence should be addressed to M Friedman-Einat; Email: einat@agri.huji.ac.il)
}

\begin{abstract}
We report on the construction of a leptin bioassay based on the activation of chicken leptin receptor in cultured cells. A human embryonic kidney (HEK)-293 cell line, stably transfected with the full-length cDNA of chicken leptin receptor together with a STAT3-responsive reporter gene specifically responded to recombinant human and Xenopus leptins. The observed higher sensitivity of chicken leptin receptor to the former is in agreement with the degree of sequence similarity among these species (about 60 and 38\% identical amino acids between humans and chickens, and between humans and Xenopus respectively). The specific activation of signal transduction through the chicken leptin receptor, shown here for the first time, suggests that the transition of Gln269 (implicated in the Gln-to-Pro Zuckerfatty mutation in rats) to Glu in chickens does
\end{abstract}

not impair its activity. Analysis of leptin-like activity in human serum samples of obese and lean subjects coincided well with leptin levels determined by RIA. Serum samples of pre- and post partum cows showed a tight correlation with the degree of adiposity. However, specific activation of the chicken leptin receptor in this assay was not observed with serum samples from broiler or layer chickens (representing fat and lean phenotypes respectively) or with those from turkey. Similar leptin receptor activation profiles were observed with cells transfected with human leptin receptor. Further work is needed to determine whether the lack of leptin-like activity in the chicken serum samples is due to a lack of leptin in this species or simply to a serum level of leptin that is below the detection threshold.

Journal of Endocrinology (2008) 197, 325-333

\section{Introduction}

The chicken leptin receptor (CLEPR) gene, which has been cloned in our laboratory (Horev et al. 2000) and by others (Ohkubo et al. 2000), was the first leptin receptor (LEPR) cloned in a nonmammalian organism. It exhibits about $60 \%$ sequence similarity to its mammalian orthologues at both the nucleotide and amino acid levels. The turkey LEPR gene has also been cloned and found to share more than $90 \%$ predicted amino acid similarity with that from chicken (Richards \& Poch 2003). Mapping the CLEPR to chromosome 8 (Dunn et al. 2000) demonstrated its syntenic position relative to that of the human LEPR. In general, the tissue-specific pattern of expression of the chicken and turkey LEPRs parallels that of mammalian LEPRs, with some variations (Horev et al. 2000, Ohkubo et al. 2000, Richards \& Poch 2003).

The recent cloning of leptin and LEPR genes in Xenopus laevis (Crespi \& Denver 2006) and leptin's demonstrated role in energy balance in frogs show that this signaling pathway is ancient, likely arising very early in the evolution of vertebrates. In chickens, understanding the control of energy balance at the molecular level is of great interest for both agricultural and academic research, as it relates to a number of commercial interests, such as food intake, fat accumulation, and reproductive efficiency, among others. The study of this control mechanism in avian species lags behind due to the conflict in the identification of chicken leptin (Friedman-Einat et al. 1999, Amills et al. 2003, Richards \& Proszkowiec-Weglarz 2007). Nevertheless, as birds clearly possess genes orthologous to mammalian and frog LEPRs, it is likely that a gene for the ligand also exists in the bird genomes. Here, we describe the construction of a leptin bioassay based on the forced expression in cultured cells of CLEPR. We show that recombinant leptins originating from both humans and frogs activate CLEPR with high potency. This bioassay is expected to be valuable for the identification of CLEPR natural ligands, and for further study of this signaling pathway's role in avian growth and physiology.

\section{Materials and Methods}

\section{Cytokines}

Human leptin was kindly donated by Prof. Arieh Gertler (The Hebrew University, Rehovot, Israel). Xenopus leptin was prepared as described previously (Crespi \& Denver 2006). 
Interferon- $\alpha$ (IFN- $\alpha)$ was a kind gift from Dr Daniela Novic and Dr Menachem Rubinstein at the Weizmann Institute of Science, Rehovot, Israel.

\section{Constructs}

The reporter construct $\mathrm{pAH} 32$, an expression vector transactivated by leptin, has been previously described (Rosenblum et al. 1998). This construct contains a trimer of the STAT3-binding element derived from interferon regulatory factor 1 , preceding the herpes simplex virus thymidine kinase minimal promoter and the luciferase cDNA. The expression vector pgkPuro, containing the puromycin resistance gene, was kindly provided by Prof Moshe Oren at the Weizmann Institute of Science. The expression vector pCMV-NSV was contains the cytomegalovirus promoter and the SV 40t-intron and early polyadenylation site.

\section{Constructing the CLEPR expression vector}

PCR fragments encompassing the full-length CLEPR and the primers used for their amplification are described in Fig. 1 and Table 1 respectively. In the forward primer of the first fragment, a 'KOZAK' sequence taken from the chicken $\beta$-actin gene was inserted upstream of the ATG codon to enhance efficient translation of the mRNA.

Each fragment of the expected-size PCR product was cloned into pGEM-T vector system from Promega. Several independent clones of each fragment were sequenced with Sp6 and the T7 primers, enabling verification of the complete sequence, including primers from both the $3^{\prime}$ and $5^{\prime}$ ends of the inserted fragment. For each fragment, about four independent clones were sequenced and the fragments with the correct sequences were gel-purified from pGEM-T. Fragment I was subcloned into the NotI-XmaI sites of pBluescript (Stratagene). Fragment II was subcloned downstream of fragment I, using the XmaI and EcoRI sites. Fragment III was cloned downstream of fragment II using the EcoRI-HindIII sites, and fragment IV was then cloned into the HindIII-KpnI sites. The full-length CLEPR was excised using NotI and KpnI and cloned into the NotI and $K p n I$ sites of a pCMV expression vector between the CMV promoter/enhancer and the SV40 $\mathrm{t}$ intron and the $3^{\prime}$ untranslated region.

\section{Cell culture}

The human embryonic kidney HEK-293 cell line was obtained from the American type culture collection. Cells were grown in growth medium containing Dulbecco's modified eagle medium (DMEM), $10 \%$ (w/v) fetal calf serum, $50 \mu \mathrm{g} / \mathrm{ml}$ streptomycin, and $50 \mu \mathrm{g} / \mathrm{ml}$ penicillin. Cells were incubated at $37^{\circ} \mathrm{C}$, in an atmosphere containing 5\% $\mathrm{CO}_{2}$. Clones transfected with plasmid DNA were maintained in growth medium with the addition of $2 \mu \mathrm{g} / \mathrm{ml}$ puromycin.

\section{Transfections}

To generate the test clones, HEK-293 cells were transfected with three constructs: CLEPR, pAH32, and pgkPuro, at a molar ratio of 4:4:1 respectively. To generate the control cell lines, the cells were transfected with two constructs: pAH32 and pgkPuro, at a ratio of 10:1 respectively. Transfections were performed using lipofectamine (Gibco/BRL) as described in the manufacturer's protocol. About 40 clones were collected from each transfection and each was tested for the activation of luciferase using human leptin $(100 \mathrm{ng} / \mathrm{ml})$ and IFN- $\alpha(100 \mathrm{U} / \mathrm{ml})$. Whereas IFN- $\alpha$ is believed to operate through an endogenous receptor, thus revealing the presence of the inducible reporter construct, human leptin requires the presence of exogenous LEPR. Out of about 40 clones isolated, 20 were found to express the reporter construct and about 10 were found to respond well to the recombinant human leptin and to give a positive signal with radioactive CLEPR probe by northern analysis (see Results). One of the clones, which displayed stable and significant leptininduced luciferase activity, was used for subsequent analyses (test clone). A control cell line (with no LEPR) was chosen among the control clones based on its relative high sensitivity with respect to response to IFN- $\alpha$.

\section{HEK-293 leptin assay}

Test and control cultures, in their log growth phase, were briefly dissociated with trypsin and resuspended in the growth medium described above. Resuspended cells were plated in 24-well tissue-culture plates (Nunc, Danyel Biotech, Rehovot, Israel) at a concentration of $5 \times 10^{5}$ cells per well in a $500 \mu \mathrm{l}$ final volume. After 16-20 h, the medium in each well was replaced with $300 \mu$ DMEM (Gibco/BRL), supplemented with $1 \mathrm{mM}$ $\mathrm{CaCl}_{2}$. Empirically, this addition of calcium was found to

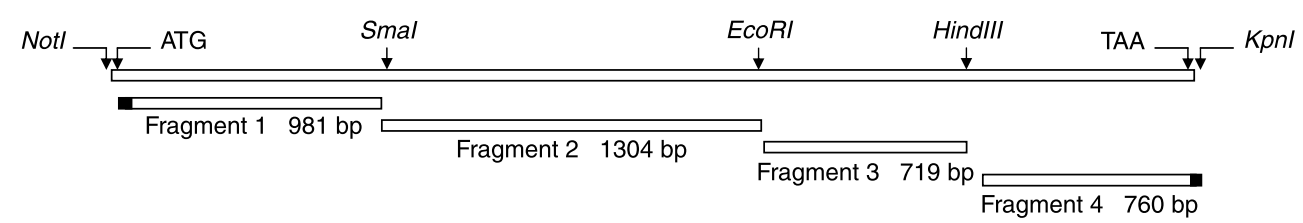

Figure 1 Schematic drawing of the strategy for building the CLEPR full-length cDNA. Black boxes indicate extended primer sequences to include Notl site and a 'KOZAK' sequence in the 5 ' - as well as a stop codon and Kpnl site at the $3^{\prime}$-ends of the cDNA. These sequences are indicated in Table 1. 
Table 1 Primers used for the generation of the full-length CLR

\begin{tabular}{|c|c|c|c|}
\hline & $\begin{array}{l}\text { Fragment } \\
\text { size (bp) }\end{array}$ & $\begin{array}{l}\text { Exon } \\
\text { included }\end{array}$ & Primer sequence \\
\hline \multicolumn{4}{|l|}{$\begin{array}{l}\text { Fragment } \\
\text { number }\end{array}$} \\
\hline 1 & 981 & $3-8$ & $\begin{array}{l}\text { For: 5'-CGAGCGGCCGCCACACCCGCCACCAGTTCGCCATGTATCATCAAATCATTCTGACC-3' } \\
\text { Rev: } 5^{\prime} \text {-ACAGTGTGCTCCATTCACTCC-3' }\end{array}$ \\
\hline 2 & 1304 & $8-16$ & $\begin{array}{l}\text { For: 5'-GCTCAAGTGAGGTGCAAGAG-3' } \\
\text { Rev: } 5^{\prime} \text {-TGCACAGCATTCACTGTGCTC-3' }\end{array}$ \\
\hline 3 & 719 & $16-20$ & $\begin{array}{l}\text { For: 5'-CCATGGACTGAAAGCACACAC-3' } \\
\text { Rev: 5'-GTGAACATGGAATCAAGCAC-3' }\end{array}$ \\
\hline 4 & 760 & 20 & $\begin{array}{l}\text { For: 5'-AGTGCTGGAAGACATCAGTG-3' } \\
\text { Rev: 5'-CTCGGTACCTTACTTATCGTCGTCGTCCTTGTAATCACAGCTGTTCTCTGTGGTCTC-3' }\end{array}$ \\
\hline
\end{tabular}

reduce the activation of the control cells by chicken serum samples. Cytokines (recombinant human leptin, Xenopus leptin, or human IFN- $\alpha$ ) at the indicated concentrations, or $30 \mu \mathrm{l}$ aliquots of serum samples, were added to the incubation medium for $3 \mathrm{~h}$. For incubation with purified proteins (leptins and INF), medium was supplemented with $2 \%$ (W/V) albumin (Sigma) for enhancing protein stability. Medium was then aspirated and the cells were lysed by adding $100 \mu$ Promega cell lysis reagent. A $40 \mu \mathrm{l}$ aliquot of each cell lysate was mixed with $100 \mu \mathrm{l}$ Promega luciferase assay reagent. Luciferase activity was measured using the TD20e luminometer (Turner Design, Mountain View, CA, USA). The measured luminescence was normalized to the amount of protein in each well. Protein concentration was measured by the Bradford assay according to the manufacturer's protocol (Bio-Rad) following 150-fold dilution of the cell lysate.

\section{Preparation of $R N A$}

RNA was extracted from the hypothalamus of 3-month-old Leghorn chickens using RNAzol B (Tel-Test Inc., Talron, Rehovot, Israel) according to the manufacturer's instructions. Briefly, hypothalamuses from four chickens were extracted in $1 \mathrm{ml}$ RNAzol using a homogenizer, centrifuged at $10000 \mathrm{~g}$, and the upper phase was extracted with a phenol-chloroform solution $(1: 1 \mathrm{v} / \mathrm{v})$. After separation of the aqueous phase by centrifugation as described above, the upper phase was treated with $1 / 10$ volume of $10 \mathrm{mM} \mathrm{Na}$-acetate and $2 \cdot 4$-fold ethanol for precipitation of the RNA.

Preparation of RNA from cultured cells was performed from near-confluent cultures in $80 \mathrm{~mm}$ plates using $1 \mathrm{ml}$ RNAzol B per plate. The rest of the procedure was as described above.

All experiments on animals were approved by the local Ethics Committee.

\section{Reverse transcription (RT) and PCR}

To generate long cDNA templates from the hypothalamusderived RNA, a thermostable RT (Tth RT, Ambion,
Agentech, Tel-Aviv, Israel) was used following the manufacturer's protocol. Briefly, reactions were incubated in a Hybaid thermal cycler (Hybaid, Tamar, Jerusalem, Israel); elongation was for $50 \mathrm{~min}$ at $60{ }^{\circ} \mathrm{C}$, followed by $15 \mathrm{~min}$ at $70{ }^{\circ} \mathrm{C}$. For other purposes, RTwas performed with $200 \mathrm{U}$ of Superscript II RT (Invitrogen) in a $20 \mu \mathrm{l}$ reaction containing $0 \cdot 15 \mu \mathrm{g}$ random hexamers, $1 \times \mathrm{RT}$ buffer (Invitrogen), $10 \mathrm{mM}$ dithiothreitol, and $0.5 \mathrm{mM}$ deoxynucleoside triphosphates. Reactions were incubated in the thermal cycler for $50 \mathrm{~min}$ at $42{ }^{\circ} \mathrm{C}$, followed by $15 \mathrm{~min}$ at $70{ }^{\circ} \mathrm{C}$.

Conventional PCR and gel electrophoresis were performed on $1 \mu \mathrm{l}$ cDNA with $0.5 \mathrm{U}$ recombinant Taq DNA polymerase (Ready Mix Taq DNA Polymerase Purple $\times 2$, Talron) in a $50 \mu \mathrm{l}$ reaction mixture containing the ready mixture and $0.5 \mathrm{p} / \mathrm{mol}$ from each of the forward and reverse primers. The reaction was incubated in a Hybaid thermal cycler for $3 \mathrm{~min}$ at $94^{\circ} \mathrm{C}$, followed by two 5 cycles of $94^{\circ} \mathrm{C}$ for $30 \mathrm{~s}, 65^{\circ} \mathrm{C}$ and $60^{\circ} \mathrm{C}$ (for the second 5 cycles set) for $30 \mathrm{~s}$, and $72{ }^{\circ} \mathrm{C}$ for $90 \mathrm{~s} ; 25$ cycles of $94^{\circ} \mathrm{C}$ for $30 \mathrm{~s}, 55^{\circ} \mathrm{C}$ for $30 \mathrm{~s}$, and $72{ }^{\circ} \mathrm{C}$ for $90 \mathrm{~s}$; and a $10-\mathrm{min}$ final extension step at $72{ }^{\circ} \mathrm{C}$. Amplicons were analyzed by $1 \cdot 2 \%(\mathrm{w} / \mathrm{v})$ agarose gel electrophoresis.

\section{Subcloning}

PCR fragments were treated with Wizard PCR or gel purification kits (Promega, Biological Industries) and subcloned using either the pGEM-T kit (Promega) or the Promega $T_{4}$ DNA ligase kit. Ligation reactions were begun in room temperature water, and placed in a cold room for gradual cooling overnight. Transformation of the ligation products into DH5-competent bacteria (Promega, Biological Industries) and plasmid preparation were performed according to standard procedures (Sambrook 2001).

\section{Northern hybridization}

Northern hybridization was performed on total RNA. The samples were denatured for $5 \mathrm{~min}$ at $65^{\circ} \mathrm{C}$, separated in a $1 \cdot 2 \%$ agarose $/ 2 \cdot 2 \mathrm{M}$ formaldehyde gel, and blotted onto a 
Qiabrane nylon membrane (Qiagen, Bio-Lab Laboratories Ltd) according to the standard procedures (Sambrook 2001). The membrane was prehybridized for $2 \mathrm{~h}$ at $42{ }^{\circ} \mathrm{C}$ in a solution containing $5 \times \mathrm{SSC}, 50 \%(\mathrm{v} / \mathrm{v})$ formamide, $5 \times$ Denhardt's solution, $10 \%(\mathrm{w} / \mathrm{v})$ dextran sulfate, $1 \%(\mathrm{w} / \mathrm{v})$ SDS, and $100 \mathrm{mg} / \mathrm{ml}$ denatured salmon sperm DNA. Hybridization was carried out overnight at $42{ }^{\circ} \mathrm{C}$ in the same solution but with the addition of ${ }^{32} \mathrm{P}$-labeled full-length CLEPR cDNA (the NotI-KpnI fragment). Labeling was performed using the random primer labeling kit (Amersham Pharmacia Biotech). Exposure times were $24 \mathrm{~h}$ for the transiently transfected clone and 4 days for the stable clones. The size of the detected band was estimated according to the position of the $18 \mathrm{~S}$ and $28 \mathrm{~S}$ rRNA following ethidium bromide staining of the gel.

\section{Serum samples}

Human serum samples were collected from obese and lean subjects and analyzed for leptin by RIA in Prof Donny Strosberg's laboratory as described previously (Friedman-Einat et al. 2003). Informed consent was obtained from all subjects. Samples from pre- and post partum cows were a gift from Prof Ami Arieli (the Hebrew University, Rehovot, Israel). The chicken serum samples were taken from layer (Lohman) and broiler (Cobb) hens at about 30 weeks of age. Both hen types were purchased from local husbandries when they were a day old and raised with free access to feed and water (according to the NRC Manual) in our experimental farm. Samples from feedrestricted Lohman layers were obtained following $20 \mathrm{~h}$ of fasting. Samples from turkeys and feed-restricted broilers were taken from commercial farms.

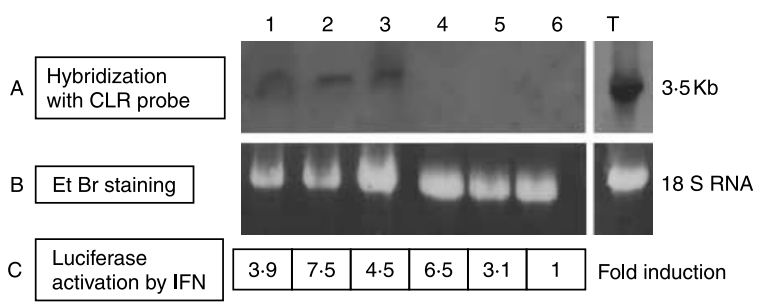

Figure 2 Characterization of the transfected clones. (A) Northern hybridization using the CLEPR-specific probe showing three LEPR positive clones (lanes 1-3), two clones transfected with the reporter construct only (lanes 4 and 5), the parental line (lane 6) and the parental line $72 \mathrm{~h}$ after transient transfection with the CLEPR (lane T). (B) Ethidium bromide staining of the gel before blotting indicating the integrity of the RNA. (C) Reporter gene activation following incubation with IFN- $\alpha$ (IFN). No luciferase activation was detected in the parental line that does not contain the reporter gene (fold induction $=1$ ). Cells were grown in 24 -well plates and incubated in triplicates with 100 IU of IFN- $\alpha$ for $3 \mathrm{~h}$. Luciferase activity was measured using luciferin (Promega) and luminometer (Turner Biosystems). Fold induction was calculated by dividing the signal obtained in the presence and absence of IFN- $\alpha$. Means of triplicate are shown. Standard error was about $10 \%$ in all cases (not shown).

\section{Results}

Bioassay construction

Generation of full-length CLEPR with the available proofreading PCR enzymes always resulted in sequences with some mutations and deletions (not shown). Therefore, the full-length
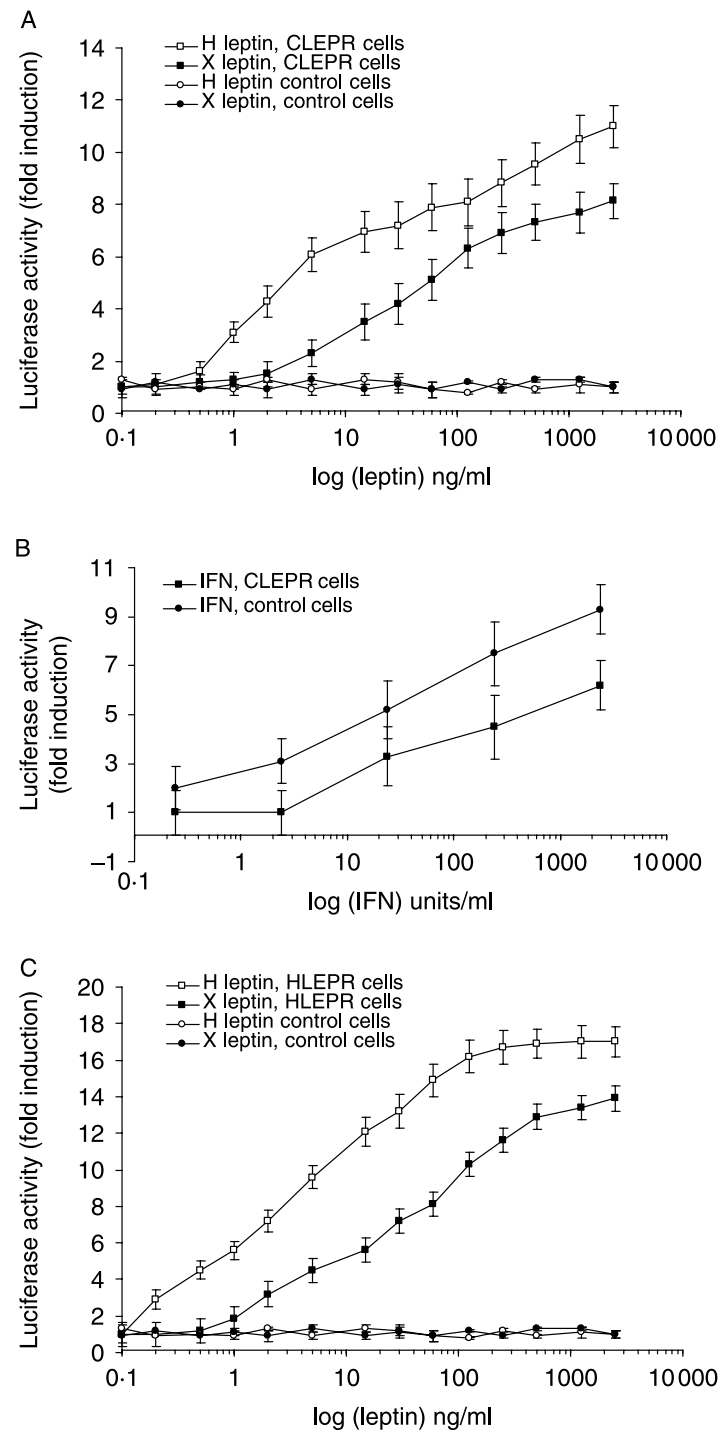

Figure 3 Stimulation of luciferase activity in the stably transfected clones by recombinant human and Xenopus leptins and by IFN- $\alpha$. (A) The CLEPR expressing cells (squares) and the control cells (circles) were incubated with the indicated amounts of either human leptin (filled squares, filled circles) or Xenopus leptin (open squares, open circles), as described in Fig. 2. (B) The human-LEPR expressing cells (HLEPR, squares) and control cells (circles) were incubated with the recombinant leptins described in A. (C) The CLEPR expressing cells (squares) and the control cells (circles) were incubated with IFN- $\alpha$. Luciferase activity was measured as described in Fig. 2. Results represent the average of three measurements \pm s.D. and are representative of three independent experiments. 
cDNA was tailored from smaller fragments, each selected by sequencing as described in Materials and Methods. The resultant expression vector was stably introduced into HEK-293 cells together with a reporter construct ( $\mathrm{pAH} 32$ ), which included the firefly luciferase gene under the control of the STAT3responsive promoter (Rosenblum et al. 1998). Control cells were transfected with the reporter construct alone for the detection of possible nonspecific activation mediated independent of the LEPR. Several transfected clones selected by neomycin resistance were analyzed for expression of CLEPR mRNA by northern hybridization (Fig. 2) using a CLEPRspecific probe. A specific band of the expected size (about 3.5) was detected in the clones stably transfected with the CLEPR expression vector (lanes 1-3), while no signal could be observed in the clones transfected with the reporter construct only (lanes 4 and 5) or the parental cell line (lane 6). As expected, signal intensity with the CLEPR probe was much stronger in transiently transfected HEK-293 cells (lane T) than in the stable clones. The response of these clones to IFN- $\alpha$, reflecting the activation of the reporter gene through an endogenous receptor, is shown in Fig. 2C. The five transfected cell lines analyzed responded to IFN- $\alpha$ by induction of luciferase activity, indicating the expected cytokine-induced activity of the reporter luciferase gene. Since the reporter gene promoter is a cytokine-responsive element, control cell lines that do not express LEPR were needed to detect possible nonspecific activation mediated independently of the LEPR.

\section{Specific activation of CLEPR by recombinant human and Xenopus leptins}

As shown in Fig. 3, recombinant leptins from both humans and Xenopus specifically induced luciferase activity in the CLEPRexpressing cell line. The dose-response curves shown in Fig. 3A demonstrate a significant (twofold or greater) induction of luciferase activity at minimum effective doses of $0.7 \mathrm{ng} / \mathrm{ml}$ human leptin, when compared with $4 \mathrm{ng} / \mathrm{ml}$ Xenopus leptin. Induction levels reached a plateau at about 11 - and 8 -fold for the human and Xenopus leptins respectively. The higher sensitivity of the assay to induction by human versus Xenopus leptin was compatible with the higher degree of amino acid similarity between human and chicken LEPRs than between those of chicken and Xenopus (Table 2). The control cell line, containing only the reporter construct, did not respond to any of the recombinant leptins (Fig. 3A), indicating that this cell line does not respond to human and Xenopus leptins without the introduction of an exogenous LEPR gene. In Fig. 3B, the response of both the control and CLEPR-expressing cell lines to recombinant IFN- $\alpha$ indicated that the control cell line is not less sensitive to luciferase induction than the CLEPR cells when activated through an endogenous receptor. In fact, the control cells responded with even higher sensitivity than the LEPRexpressing cells. An additional control (shown in Fig. 3C) consisted of obtaining a dose-response curve for human and Xenopus leptins using a cell line harboring the human LEPR gene instead of the CLEPR. This cell line, described previously (Marikovsky et al. 2002, Friedman-Einat et al. 2003), exhibited a response similar to that of the CLEPR cell line (Fig. 3A), albeit with somewhat higher sensitivity.

\section{Comparison of human, chicken, and Xenopus LEPR amino acid sequences}

Amino acid-sequence comparison of the LEPR genes from humans, chickens, and Xenopus is shown in Fig. 4 and Table 2. Of the various known functional motifs, boxes 1 and 2 in the intracellular domain of the LEPRs have been implicated in binding and activation of Jak kinases (Ihle 1995, Ghilardi \& Skoda 1997), while box 3 and the three tyrosine residues Y963, Y1077, and Y1138 have been implicated in the activation of STAT3 (White et al. 1997a). The predicted single transmembranal domain, characteristic of the class I cytokine receptor family, was found to be highly hydrophobic in all three molecules. The two WS $\times$ WS residues suggested to contribute to ligand-recognition in cytokine receptors, and the cytokine receptor homology $(\mathrm{CRH})$ domains, implicated in leptin binding, were well conserved. The $\mathrm{C}$ residues characteristic of the fibronectin type II modules (Zabeau et al. 2005) are indicated. Thus, despite the low sequence similarity among these sequences, all of the known functional motifs

Table 2 Amino acid similarity of the LEPRs among chicken, Xenopus human, and bovine. Comparisons were done using BLAST

\begin{tabular}{|c|c|c|c|}
\hline & Identities & Positives & Gaps \\
\hline \multicolumn{4}{|l|}{ Comparison } \\
\hline \multicolumn{4}{|l|}{ A. The full-length LEPR } \\
\hline Chicken - Xenopus & $38 \%(447 / 1166)$ & $58 \%(680 / 1166)$ & $3 \%(39 / 1166)$ \\
\hline Chicken - Human & $47 \%(550 / 1152)$ & $64 \%(746 / 1152)$ & $2 \%(28 / 1152)$ \\
\hline Chicken - Bovine & $48 \%(557 / 1150)$ & $66 \%(761 / 1150)$ & $2 \%(24 / 1150)$ \\
\hline \multicolumn{4}{|c|}{ B. The leptin-binding domain } \\
\hline Chicken - Xenopus & $46 \%(151 / 324)$ & $64 \%(208 / 324)$ & $1 \%(5 / 324)$ \\
\hline Chicken - Human & $61 \%(198 / 322)$ & $77 \%(248 / 322)$ & $0 \%(3 / 322)$ \\
\hline Chicken - Bovine & $60 \%(196 / 322)$ & $77 \%(250 / 322)$ & $0 \%(3 / 322)$ \\
\hline
\end{tabular}

Accession numbers are: human LR, gi40254464; bovine LR, gi90991698; CLR, gi49170082; Xenopus LR, gi13205944. 
Human

Chicken

Xenopus

Human

Chicken

Xenopus

Human

Chicken

Xenopus

Human

Chicken

Xenopus

Human

Chicken

Xenopus

Human

Chicken

Xenopus

Human

Chicken

Xenopus

Human

Chicken

Xenopus

Human

Chicken

Xenopus

Human

Chicken

Xenopus

Human

Chicken

Xenopus

Human

Chicken

Xenopus

Human

Chicken

Xenopus

Human

Chicken

Xenopus

Human

Chicken

Xenopus

MTCOKFCVVLLHWFFTYVITAFNLSYPITPWRFKLSCMPPNSTYDYFLLPAGLSKNTSNSNGHYFTAVEPKFNSSGTHFS 80 MYHQI ILTMSLLLGFLHVAAAHCMVHEIHPRSFTLPCLLLNETSS---SPSAAGVVRSRSGWRREHGVAETNPS- - - - - L 72 MFWHWILPFFLLLRYMQITAAYSEMYWTPPSDFFLTCILTNKSVN-YPLLAGILQNKSDISGKYDTLEGRSDFRCTHLAD 79

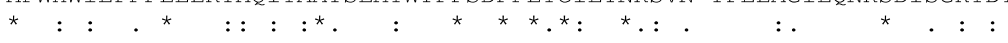

NLSKTTFHCCFRSEQDRNCSLCADNIEGKTFVSTVNSL-VFQQIDANWNIQCWLKGDLKLFICYVESLFKNLFRNYNYKV 159 LMDEESFLCCLWSNNNASCSLYSANMQARMLIPSEMS ISASQERDSNWNIECWVEGKLDLLVCSLQ--FPKFHVRLDMKV 150 LKSQGRVSCCLWDHLNTNFSSQNGVAELKEMLFASFAS-DIQLEDFSWKVQCSFEEKVNTLICDLQLLPETKHIVTDYRI 158

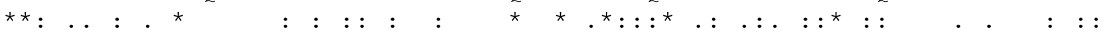

HLLYVLPEV-LEDSPLVPQKGSFQMVHCNCSVHECCECLVPVPTAKLNDTLLMCLKITSGGVIFQSPLMSVQPINMVKPD 238 HLLYAVSELSLGDASTSSLKRTALAAQCNCSEYGKCECHVPSP--RLNHTYVMWLKTVIGVTPLWSPLMSVKPIDIVKPE 228 SLHYSLVAK------SELKG---TAECRCFGYEKCECIVPSV--KFNDTYILWIEILNITALLHSPPMSVVPYHIVKPD 226

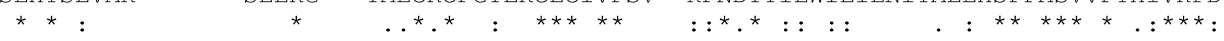

PPLGLHMEITDDGNLKISWSSPPLVPFPLQYQVKYSENSTTVIREADKIVSATSLLVDSILPGSSYEVQVRGKRLDGPGI 318 PPLNVRLEMTERGQVKICWSEPVPMPYPLRCEVNISGNSDQNDWQVVQVALNTSLDIDNMLLDSSSFAQVRCKSHCGPGF 308 PPDDLRAEIMEQGTLKVFWLKPISAAYELQYQVRYTVKAAETNSQVYLLVNETSVIISDIQPCTEMVIEVRCINLHKSGL 306

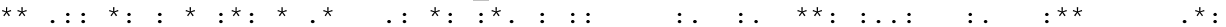

PRVFTT-QDVIYFPPKILTSVGSNVSFHCIYKKENKIVPSKEIVWWMNLAEKIPQSQYDVVSDHVSKVTFFNLN 397 TLYNLNVGAEVLYFPTKILTSVGSNVSFHCIYKNKTOSVASKKIVWWLNLAEEIPESQYTLVNDRVSKVTLFNLK 388 KTWVLNS-QDVFYFPQKVLVSSGSSTSVSCLFCDNGKKVPSSNITWWLNFGEKIPKHQYRATSDYFSKVFLTHLN 385

ETKPRGKFTYDAVYCCN-EHECHHRYAELYVIDVNINISCETDGYLTKMTCRWSTSTIQSLAESTLQLRYHRS-SLYCSD 475 ATKPRGSFFYNALYCCHQNRECHHRYAELYVVDVNINIKCETDGYLTKMTCRWSANPNALLLGSSLQLKYHMS-KIYCSN 467 TTKPKGKFRYDALHCC INHNECHHRYAEIYVLDVNISISCETDGNQKMMTCRWSSQNMTLPEGSVLQFKYYRRNKLYCLD 465

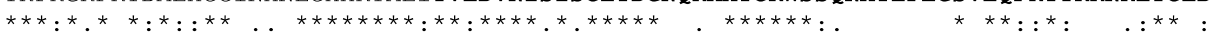

IPSIHPISEPKDCYLQSDGFYECIFQPIFLLSGYTMWIRINHSLGSLDSPPTCVLPDSVVKPLPPSSVKAEITINIGLLK 555 FPSTPPESEVKECHFQRNHSYECTFQPVFLLSGYTMWIELKHSLGTLESSPTCVVPADVVKPLPPSNIKAEITRNDGLLN 547 KDLKGNVPISKDCQLQMDGFYECTFEPVHLVSGYIMWIEIQHHLGALNSPPVCILPINTVKPLAPSRVRAEMTKGSGHLY 545

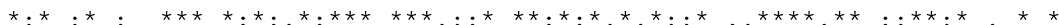

ISWEKPVFPENNLQFQIRYGLSGKEVQWKMYEVYDAKSKSVSLPVPDLCAVYAVQVRCKRLDGLGYWSNWSNPAYTVVMD 635 VSWTNPVFTNDDLKFQIRYAVNREELTWELYEVLSVPTRSAVIEV-QLCVEYIVQIRCRALDGLGYWSNWSRSAYAAVKD 626 VSWKRPALPSTDLQFOVRYCLQGQGI IWKVQVLDIFEEEFVSIQVPDVCASYTVQVRSRRTDGVGYWSDWSQPVHTVVRD 625

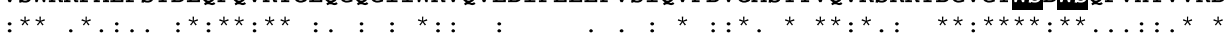

IKVPMRGPEFWRI INGDTMKKEKNVTLLWKPLMKNDSLCSVQRYVINHHTSCNGTWSEDVGNHTKFTFLWTEQAHTVTVL 715 IQAPLHGPEFWRTVTEDPATGQKNVTLLWKPLMKNHSLCSVSRYVIKHQTSENTSWSEYVDNGTTCSFPWTESTHTITIL 706 IRVPLQGPTFWRTTHNNPMQKGDNISIIWQPLPSEHSLCSIQGYEVIHLNSKNVTWSKYVGNTTKHTFTLSDNAVTVTLL 705

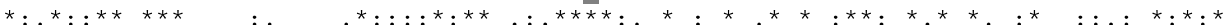

AINSIGASVANFNLTFSWPMSKVNIVQSLSAYPLNSSCVIVSWILSPSDYKLMYFIIEWKNLNEDGEIKWLRISSSVKKY 795 AVNSIGASSVNFNLTLSQQMSTVNAVQSLIAYPVNSTCVILTWTLSPQIYVITSFIIEWRNLNKEEEMKWVQVPPNISKH 786 AVNSLGYSLTNSKLTF SCEMSTVTSVESFRVYHMNNTCAVAVWTMLPKSDMPLEF IVEWKNLGNEEKVQWMNIPQNMSRC 785

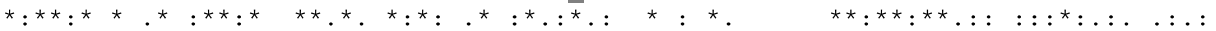

YIHDHFIPIEKYQFSLYPIFMEGVGKPKI INSFTQDDIEKHQSDAGLYVIVPVI ISSSILLLGTLLISHQRMKKLFWEDV 875 YIYDHF ILIEKYRFSLYPVFAAGVGKSRATDQF SKDGYASQTSSN-LYMVLPIVISTSVLLLGALLVSHRRMKKLLWEDV 865 YIEDNFFAIEKYVFSLYPVFPEGVGRSKVVNGFSTVELTEAPKDAGLYVILPVISF SVFLLMGTILISHQRMKKLFWKDV 865 $* * * *: * * * * * * * * * * * *: .:: *$ : PNP
PNP
PNP KNCSWAQGLNFQKPETFEHLFIKHTASVTCG KNCSWAQGVDFQOPETFEHLFVKHPEAMSFEKHCSWAQGVNFEKPDTLENLFMKHHKHPANG

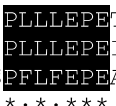

TISEDISVDTSWKNKDEMMPTTVVSLLS-TTDLEKGSV 953 IVLEDISVTKALEQEDTODFLVLDSTFTKPEDSEHDSA 944 AVFEDLSIDKQVPHEIIDNIPAVNSLFTVSEEPDHDSA 945

CISDQFNSVNFSEAEGTEVTYEDESQRQPFVKYATLISNSKPSETGE-EQGLINSSVTKCFSSKNSPLKDSFSNSSWEIE 1032 CPSSHFSGRSSLECSPSDPTSG-ETASQSNIKYATVITNSRSGGLYE-QNKNPRCHFDGCFLAEDSLAAGACSGSSWELG 1022 CESSNFSSGCAFETDHOEMVYS--SICQSSIEYATIMNNTQOCRKYSSERKTSLSSFDGCLLGNSSMVIG-----NHDVD 1018 **. : . *. : : : $\quad$ *. : : ***: : *::

AQAFFILSDQHPN----IISPHLTFSEGLDELLKLEGNFPEENNDKKSIYYLGVTSIKKRESGVLLTDKSRVSCPFPAPC 1108 NEAFLLLPDQPGSQP--CKTLSLISSEGFSEPSDQDDAFTDGGSPERGLHYLGITSLGKRENDIFLTESSRLMCHFHTAD 1100 KQTLVFLAGLHTKQPDKMSCNSTVSSEGFSEPLDHEDSFLEADGLERNLYYLEFGSIQQCGQQDCYSEKPLGTFPFQENI 1098
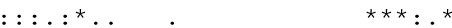
$:$.

LFTDIRVLQDSCSHFVENNINLGTSSKKTFAS LLRGVGFLQNTP----PNLNAFIQSSIKAIVP SYKEIDFKKDKASEFIDNYD-IKNSFKKAFL

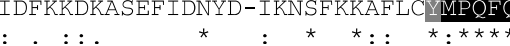
TCSTQTHKIMENKMCDLTV 1165 MTAAKVQETTENSC----- 1148 THSIKLPGEMESETLN--- 1151 *.. 
and domains of LEPR were conserved in terms of both sequence and position.

\section{Detection of leptin activity in chicken serum samples}

Given that physiological serum leptin concentrations in mammals range from about 3 to $80 \mathrm{ng} / \mathrm{ml}$ (Tomimatsu et al. 1997, Friedman-Einat et al. 2003, Nkrumah et al. 2007), we expected to be able to detect leptin activity in the serum samples with this bioassay. As shown in Fig. 5, human serum samples from obese and lean subjects, diluted 10-fold, induced luciferase activity by factors of $6.7( \pm 0.5)$ and 2.5 $( \pm 0 \cdot 4)$ respectively. This level of activity is compatible with the amount of leptin immunoreactivity determined in these samples by RIA (Friedman-Einat et al. 2003), i.e. 75 and $10 \mathrm{ng} / \mathrm{ml}$, in the original samples (tenfold more concentrated than the incubated doses). Serum samples from pre- and post partum cows also showed the expected high and low leptinlike activities (Andrew et al. 1994, Block et al. 2001). However, serum samples from broiler and layer chickens and turkeys under free-access feeding, (Fig. 5) or from the same strains but under feed-restricted regimens (not shown) did not exhibit significant induction of reporter activity in this assay. It may be that leptin levels in these poultry samples are below the threshold of detection by the bioassay.

\section{Discussion}

In this work, we demonstrated the possibility of employing CLEPR-transfected HEK-293 cells for the detection of leptin activity. CLEPR-expressing cells responded specifically, via the activation of a reporter gene, to recombinant human and Xenopus leptins despite high divergence in the predicted amino acid sequence of the LEPR among these species. This in vitro cross-CLEPR activation appears to be stronger for human than for frog leptin, compatible with the significantly higher degree of sequence similarity between human and chicken LEPRs.

Besides providing a rapid and simple experimental tool for measuring leptin activity, this assay indicates that CLEPR can bind mammalian and Xenopus leptins and activate STAT3dependent signaling. It is also evident that the transition of Gln269 to Glu in the chicken homologues does not impair CLEPR activity. This is in contrast to the Gln269-to-Pro transition, implicated in the fatty mutation in rats (White et al. 1997b).
The response of the CLEPR-harboring cells to the recombinant leptins was similar to that of our previously reported cell line expressing human LEPR (Marikovsky et al. 2002, Friedman-Einat et al. 2003) It should be noted, however, that the two bioassays cannot be used for accurate comparisons of leptin affinities since each of the LEPR constructs is driven by a different promoter and the copy number of LEPRs in each cell line is probably different as it has not been determined.

Previous analysis of predicted tertiary structures of Xenopus, rat, and pufferfish leptins (Crespi \& Denver 2006) has shown a four-helix structure that is nearly identical for the three analyzed species, despite the low sequence similarities of their predicted protein sequences (e.g. Xenopus leptin shares 35\% sequence similarity with mammalian leptins). This suggests that the conserved tertiary structure is important for receptor binding, as has been shown for other type I cytokines (Huising et al. 2006). No such structural modeling studies have been performed with the chicken leptin protein, as it does not yet appear to have been unequivocally identified (Friedman-Einat et al. 1999, Amills et al. 2003, Richards \& Proszkowiec-Weglarz 2007). Nevertheless, the abovementioned structural similarity found in the highly divergent leptins strongly suggests that the putative chicken leptin also shares a similar structure, presumably evolutionarily constrained by the structure of the receptor-binding pocket.

The leptin-binding domain in the LEPR has been localized to residues 323-640 (Fig. 5) of the human sequence (Peelman et al. 2006), which contains the second segment of the cytokine receptor domain and the fibronectin type 3 domain (residues 428-635, Fig. 5). This domain is significantly more conserved than the overall LEPR sequences between chickens and either Xenopus, human, or bovine (Table 2). This can be taken as another support for the hypothesis regarding the existence of chicken leptin, based on the same consideration of evolutionarily constraint mentioned above.

The inability to detect significant leptin-like activity in serum samples of chickens and turkeys was surprising considering the expected higher affinity of the chicken leptin to its receptor. However, taking into account the percentages of body fat, these results are in agreement with the tight correlation, found in mammals, between the amount of body fat and the level of serum leptin (Mahabir et al. 2007). The 'obese' broiler breeder hen (Cobb) raised with free access to food has only about $5 \%$ body fat, while a lean man and woman have about 15 and $20 \%$ body fat respectively (Funkhouser et al. 2000).

The demonstrated specific activation of CLEPR by human leptin is in agreement with both in vitro protein-binding assays

Figure 4 Multiple comparisons of the predicted amino acid sequences of the human, chicken, and Xenopus leptins. Amino acid sequence of the human, chicken, and Xenopus LEPRs (accession numbers: gi40254464; gi49170082; and gi113205944 respectively) are denoted by the single-letter code. Alignment was performed using the ClastalX program. ${ }^{* \prime}$ ' Indicates residues or nucleotides identical in all sequences in the alignment. ':' Indicates conserved substitutions and '.'indicates semi-conserved substitutions. Functional domains, motifs, and critical amino acids found necessary for LEPR activity in mammals are indicated as follows: Box 1, 2, and 3 are indicated by white letters and black background. The Y residues (Y963, Y1077, and Y1138) are indicated by white letters on a gray background. Cysteine residues at positions 672 and 751 of the fibronectin type III domain are indicated by white letters on gray background. The glutamine (Q) at position 269 of the human sequence, implicated in the fatty mutation in rats (transition from glutamine to proline; White et al. 1997b) is denoted by gray background. 
A

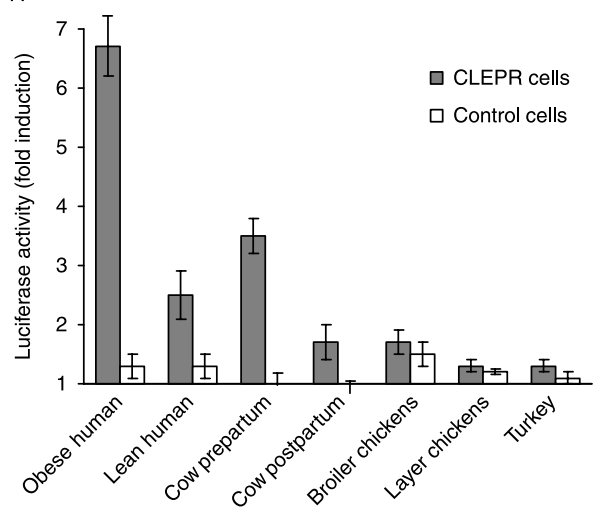

B

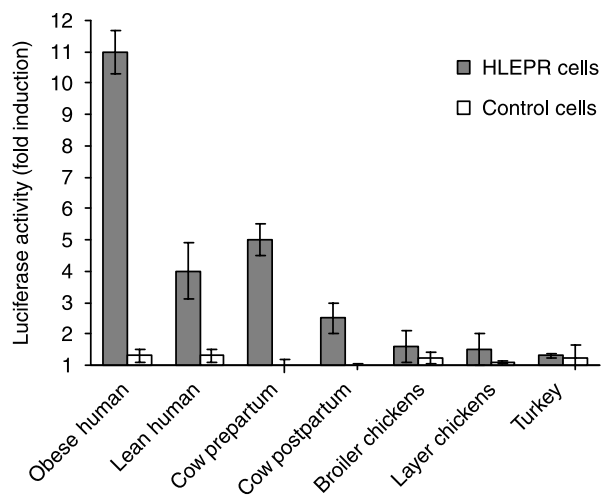

Figure 5 Detection of leptin-like activity in serum samples of human, cow, and chickens. Serum samples of the indicated sources were incubated with the CLEPR transfected cells (A) or the human LEPR transfected cells (B) and the control cell line, as described in Fig. 3. The indicated serum samples were diluted tenfold in DMEM enriched with $1 \mathrm{mM} \mathrm{CaCl}_{2}$. The sensitivity of the assay to physiological leptin levels of humans and cows but not to that of chickens is demonstrated. The experiment was done in triplicates; the mean values are of three representative experiments. Vertical lines indicate S.E.M.

that used a recombinant fragment of CLEPR containing the leptin-binding domain (Niv-Spector et al. 2005), and studies involving the administration of human leptin to chickens (Denbow et al. 2000, Kuo et al. 2005). However, some discrepancies exist within the later reports with respect to the possibility that chicken strains selected for rapid growth are leptin resistant, and with an additional publication (Bungo et al. 1999) demonstrating nonresponsiveness of young chicks to administration of mouse leptin. Therefore, the more direct demonstration of CLEPR activation of signal transduction shown here provides an important support for its functionality also in vivo.

Given that the controversial chicken leptin is highly similar to mouse leptin (95\% identical amino acids), it is not surprising that this recombinant preparation facilitated leptin-like activity in our bioassay (data not shown) and bound a recombinant fragment containing the leptin-binding domain of the CLEPR in vitro (Niv-Spector et al. 2005). Administration of this leptin in chickens resulted in inhibition of food intake (Dridi et al. 2000, Cassy et al. 2004). Additional studies have demonstrated the effect of this leptin on the immune response (Lohmus et al. 2004), the onset of sexual maturity (PaczoskaEliasiewicz 2006), egg production during and after fasting (Paczoska-Eliasiewicz et al. 2003), and downregulation of heat shock protein-70 (Figueiredo et al. 2007).

In summary, the confusion regarding the identity of chicken leptin (Friedman-Einat et al. 1999, Amills et al. 2003, Richards \& Proszkowiec-Weglarz 2007) strengthens the need for a specific bioassay for leptin activity that employs the native CLEPR. Our results add an important strength to previous reports demonstrating chickens' response to exogenous administration of various leptins (Raver et al. 1998, Denbow et al. 2000, Paczoska-Eliasiewicz et al. 2003, 2006, Lohmus et al. 2004, Kuo et al. 2005), by demonstrating for the first time a specific induction of signal transduction via
CLEPR in response to human and frog leptins in vitro. It is possible that our inability to detect leptin activity in bird serum samples was due to below-detection threshold leptin levels, which could still be of physiological significance, rather than to a lack of natural ligand for CLEPR. Therefore, fractionation and purification of poultry serum proteins could enable the detection of leptin activity using this bioassay.

\section{Acknowledgements}

This work was supported by a grant from the Chief Scientist of the Israeli Ministry of Agriculture, a grant from the USA. Public Health Service, NIDDK, and NSF grant IOS 0641587 to R J D. Contribution from the Agricultural Research Organization, the Volcani Center, Bet Dagan, Israel, No. 517 is also acknowledged. We are grateful to Chris Pelletier for assistance with preparing the recombinant Xenopus leptin. There is no conflict of interest that would prejudice the impartiality of this research.

\section{References}

Amills M, Jimenez N, Villalba D, Tor M, Molina E, Cubilo D, Marcos C, Francesch A, Sanchez A \& EstanyJ 2003 Identification of three single nucleotide polymorphisms in the chicken insulin-like growth factor 1 and 2 genes and their associations with growth and feeding traits. Poultry Science 82 1485-1493.

Andrew SM, Waldo DR \& Erdman RA 1994 Direct analysis of body composition of dairy cows at three physiological stages. Journal of Dairy Science 77 3022-3033.

Block SS, Butler WR, Ehrhardt RA, Bell AW, Van Amburgh ME \& Boisclair YR 2001 Decreased concentration of plasma leptin in periparturient dairy cows is caused by negative energy balance. Journal of Endocrinology 171 339-348.

Bungo T, Shimojo M, Masuda Y, Tachibanab T, Tanaka S, Sugahara K \& Furuse M 1999 Intracerebroventricular administration of mouse leptin does not reduce food intake in the chiken. Brain Research 817 196-198. 
Cassy S, Picard M, Crochet S, Derouet M, Keisler DH \& Taouis M 2004 Peripheral leptin effect on food intake in young chickens is influenced by age and strain. Domestic Animal Endocrinology 27 51-61.

Crespi EJ \& Denver RJ 2006 Leptin (ob gene) of the South African clawed frog Xenopus laevis. PNAS 103 10092-10097.

Denbow DM, Meade S, Robertson A, McMurtry JP, Richards M \& Ashwell C 2000 Leptin-induced decrease in food intake in chickens. Physiology and Behavior 69 359-362.

Dridi S, Raver N, Gussakovsky EE, Derouet M, Picard M, Gertler A \& Taouis M 2000 Biological activities of recombinant chicken leptin C4S analog compared with unmodified leptins. American Journal of Physiology. Endocrinology and Metabolism 279 E116-E123.

Dunn IC, Boswell T, Friedman-Einat M, Eshdat Y, Burt DW \& Paton IR 2000 Mapping of the leptin receptor gene (LEPR) to chicken chromosome 8 . Animal Genetics 31290.

Figueiredo D, Gertler A, Cabello G, Decuypere E, Buyse J \& Dridi S 2007 Leptin downregulates heat shock protein-70 (HSP-70) gene expression in chicken liver and hypothalamus. Cell Tissue Research 329 91-101.

Friedman-Einat M, Boswell T, Horev G, Girishvarma G, Dunn IC, Talbot RT \& Sharp PJ 1999 The chicken leptin gene: has it been cloned? General and Comparative Endocrinology 115 354-363.

Friedman-Einat M, Camoin L, Faltin Z, Rosenblum CI, Kaliouta V, Eshdat Y \& Strosberg AD 2003 Serum leptin activity in obese and lean patients. Regulatory Peptides 111 77-82.

Funkhouser AB, Laferrere B, Wang J, Thornton J \& Pi-Sunyer FX 2000 Measurement of percent body fat during weight loss in obese women. Comparison of four methods. Annals of the New York Academy of Sciences 904 539-541.

Ghilardi N \& Skoda RC 1997 The leptin receptor activates janus kinase 2 and signals for proliferation in a factor-dependent cell line. Molecular Endocrinology 11 393-399.

Horev G, Einat P, Aharoni T, Eshdat Y \& Friedman-Einat M 2000 Molecular cloning and properties of the chicken leptin-receptor (CLEPR) gene. Molecular and Cellular Endocrinology 162 95-106.

Huising MO, Kruiswijk CP \& Flik G 2006 Phylogeny and evolution of class-I helical cytokines. Journal of Endocrinology 189 1-25.

Ihle JN 1995 Cytokine receptor signalling. Nature 377 591-594.

Kuo AY, Cline MA, Werner E, Siegel PB \& Denbow DM 2005 Leptin effects on food and water intake in lines of chickens selected for high or low body weight. Physiology and Behavior 84 459-464.

Lohmus M, Olin M, Sundstrom LF, Troedsson MH, Molitor TW \& El Halawani M 2004 Leptin increases T-cell immune response in birds. General and Comparative Endocrinology 139 245-250.

Mahabir S, Baer D, Johnson LL, Roth M, Campbell W, Clevidence B \& Taylor PR 2007 Body mass index, percent body fat, and regional body fat distribution in relation to leptin concentrations in healthy, non-smoking postmenopausal women in a feeding study. Nutrition Journal 63.

Marikovsky M, Rosenblum CI, Faltin Z \& Friedman-Einat M 2002 Appearance of leptin in wound fluid as a response to injury. Wound Repair and Regeneration 10 302-307.

Niv-Spector L, Raver N, Friedman-Einat M, Grosclaude J, Gussakovsky EE, Livnah O \& Gertler A 2005 Mapping leptin-interacting sites in recombinant leptin-binding domain (LBD) subcloned from chicken leptin receptor. Biochemical Journal 390 475-484.

Nkrumah JD, Keisler DH, Crews DH, Jr, Basarab JA, Wang Z, Li C, Price MA, Okine EK \& Moore SS 2007 Genetic and phenotypic relationships of serum leptin concentration with performance, efficiency of gain, and carcass merit of feedlot cattle. Journal of Animal Science 85 2147-2155.
Ohkubo T, Tanaka M \& Nakashima K 2000 Structure and tissue distribution of chicken leptin receptor (cOb-R) mRNA. Biochimica et Biophysic Acta 1491 303-308.

Paczoska-Eliasiewicz HE, Gertler A, Proszkowiec M, Proudman J, Hrabia A, Sechman A, Mika M, Jacek T, Cassy S, Raver N et al. 2003 Attenuation by leptin of the effects of fasting on ovarian function in hens (Gallus domesticus). Reproduction 126 739-751.

Paczoska-Eliasiewicz HE, Proszkowiec-Weglarz M, Proudman J, Jacek T, Mika M, Sechman A, Rzasa J \& Gertler A 2006 Exogenous leptin advances puberty in domestic hen. Domestic Animal Endocrinology 31 211-226.

Peelman F, Iserentant H, De Smet AS, Vandekerckhove J, Zabeau L \& Tavernier J 2006 Mapping of binding site III in the leptin receptor and modeling of a hexameric leptin.leptin receptor complex. Journal of Biological Chemistry 281 15496-15504.

Raver N, Taouis M, Dridi S, Derouet M, Simon J, Robinzon B, Djiane J \& Gertler A 1998 Large-scale preparation of biologically active recombinant chicken obese protein (leptin). Protein Expression and Purification 14 403-408.

Richards MP \& Poch SM 2003 Molecular cloning and expression of the turkey leptin receptor gene. Comparative Biochemistry and Physiology. Part B, Biochemistry and Molecular Biology 136 833-847.

Richards MP \& Proszkowiec-Weglarz M 2007 Mechanisms regulating feed intake, energy expenditure, and body weight in poultry. Poultry Science $\mathbf{8 6}$ 1478-1490.

Rosenblum CI, Vongs A, Tota MR, Varnerin JP, Frazier E, Cully DF, Morsy MA \& Van der Ploeg LH 1998 A rapid, quantitative functional assay for measuring leptin. Molecular and Cellular Endocrinology 143 117-123.

Sambrook JARDW 2001 Molecular Cloning: A Laboratory Manual.. 3, Cold Spring Harbo, NY: Cold Spring Harbor Laboratory Press.

Tomimatsu T, Yamaguchi M, Murakami T, Ogura K, Sakata M, Mitsuda N, Kanzaki T, Kurachi H, Irahara M, Miyake A et al. 1997 Increase of mouse leptin production by adipose tissue after midpregnancy: gestational profile of serum leptin concentration. Biochemical and Biophysical Research Communications 240 213-215.

White DW, Kuropatwinski KK, Devos R, Baumann H \& Tartaglia LA 1997 a Leptin receptor (OB-R) signaling. Cytoplasmic domain mutational analysis and evidence for receptor homo-oligomerization. Journal of Biological Chemistry 272 4065-4071.

White DW, Wang DW, Chua SC, Jr, Morgenstern JP, Leibel RL, Baumann H \& Tartaglia LA $1997 b$ Constitutive and impaired signaling of leptin receptors containing the $\mathrm{Gln} \rightarrow$ Pro extracellular domain fatty mutation. PNAS 94 10657-10662.

Zabeau L, Defeau D, Iserentant H, Vandekerckhove J, Peelman F \& Tavernier J 2005 Leptin receptor activation depends on critical cysteine residues in its fibronectin type III subdomains. Journal of Biological Chemistry $28022632-22640$.

Received in final form 5 February 2008
Accepted 5 March 2008
Made available online as an Accepted Preprint
5 March 2008

